\title{
Determinants, Moderators and Consequences of Organizational Interaction Orientation
}

\section{Christian Hoops*, Michael Bücker**}

\begin{abstract}
Interaction orientation reflects the ability of a company to interact with the individual customer and to gather information from successful interactions. Four dimensions of interaction orientation are identified in the literature: customer concept, interaction response capacity, customer empowerment and customervalue management (Ramani and Kumar, 2008). This study shows that indeed a fifth dimension of interaction orientation exists and investigates the determinants, moderators and consequences of this construct. The first notable finding is that B2B companies exhibit a greater degree of interaction orientation than B2C firms. Ramani and Kumar hypothesized that in their study. We show that there are B2C industries such as financial services, whose companies also have a greater interaction orientation. This could be the reason why the authors could not prove their hypothesis. Furthermore, we examine the influence of strategic orientations on organizational performances and compare various orientations with each other.

Keywords: adaptive selling, cook's distance, customer-oriented selling, entrepreneurial orientation, environment, financial services, interaction orientation, learning orientation, market orientation, organizational culture, organizational strategy, organizational structures.
\end{abstract}

\section{Introduction}

In recent years, many studies have attempted to find new ways to positively influence various strategic orientations since the organizational culture plays an important role in achieving the company's goals (Baker and Sinkula, 1999b; Farrell, 2000; Hult, Hurley and Knight, 2004). Interaction orientation, for example, can help companies to extend their knowledge about the customer's needs and preferences (Ramani and Kumar, 2008). For companies with a higher level of organizational learning, it is easier to achieve these

* Dipl.-Stat. Christian Hoops, IPSOS Observer, christian.hoops@ipsos.com.

** Michael Bücker, Ph.D., Technical University of Dortmund, 44221 Dortmund, Germany, michael.buecker@tu-dortmund.de. 
goals because of greater abilities and more effective ways (see Buckler, 2003, p. 121).

The majority of the existing literature identifies market, entrepreneurial and learning orientation as three major constructs which directly impact organizational performance. However, only a few studies have investigated the antecedents, moderators and consequences of an interaction orientation. This study attempts to fill this gap and to develop an empirical analysis based on current literature. Furthermore, we focus on finding differences between industries and draw conclusions about the importance of several groups of determinants. Finally, we will examine whether any synergetic effects exist between interaction and market orientation.

\section{Interaction orientation}

According to Ramani and Kumar (2008), interaction orientation reflects the ability of a company to interact with the individual customer and to gather information out from successful interactions in order to create a profitable relationship with the customer. Based on statements by 48 managers the authors conceptualize interaction orientation as a second-order construct consisting of four dimensions: customer concept, interaction response capacity, customer empowerment and customer value management.

The customer concept is conceptualized as the company's belief to an ideal customer treatment. This includes customized services and products as well as individual analyses of the needs and marketing actions The customer image, which is beneficial to interaction orientation, sees the individual customer level as the examination unit and starting point of company's activities (cf. Kumar and Reinartz, 2006).

Interaction response capacity illustrates the degree of successful transactions or relationships that are due to the customer behavior in the past, both for one relevant demander and for the entire group of customers. Knowledge about as well as feedback from a certain customer is stored by companies with higher interaction orientation so that the company could draw on this knowledge in the future.

Thus, the interaction response capacity reflects the requirement of an organization to serve the heterogeneous customers individually (cf. Ramani and Kumar, 2008). Krohmer (1999, p. 176) finds out that the responsiveness to market information plays a significant role in the performance-related variables of efficiency, effectiveness and adaptability. So it can be assumed that the interaction response capacity impacts these variables and other performance indicators, too. 
Though a company is not able to provoke an interaction directly, it can be imagined that the company takes the first step. Thus, the customer empowerment as a construct of interaction orientation reflects the extent to which the company enables its customers to contact the organization in order to influence the business and cooperation. This implies that the interaction is subject to an action-reaction-cycle, thus demonstrating the need for individual activity in the theory of multiple perspectives (see Pantaleo and Wicklund, 2000).

In contrast to the other sub-constructs, customer value management does not take the extent of interaction into account, but implies the quality of the interaction partners. Homans' theory assumes that interactions are not only of benefit to at least one of the participants but also create costs (cf. Homans, 1951). Effective customer value management can help an organization to evaluate certain interactions or whole relationships in order to take this information into account in relation with later marketing activities. Since it reflects as specific customer level, this construct becomes relevant for interaction orientation (cf. Ramani and Kumar, 2008, p. 29).

Danzinger focuses on the industrial goods market, and the reflective second-order construct by Ramani and Kumar serves as a basis. Secondorder means that the latent variable interaction orientation is measured by different sub-constructs which are in contrast to formative models posited as the common cause of item behavior. However, exploratory depth interviews concluded that there is no evidence of the dimension of the belief in the customer concept for this market. Instead, the interviews identify a new sub-construct perceived as perspective taking and conceptualized as the understanding of the customer's problems. The other dimensions of interaction response capacity, customer empowerment and customer value management are confirmed by the interview data (Danzinger, 2010).

Ramani and Kumar identify different determinants of interaction orientation. Thus, they could not disprove the hypothesis that the lower the dependence on trademarks, the greater the firm's interaction orientation. This could be explained by the fact that the greater the dependence on patents and trademarks, the less the firm has to fulfill the customer's needs since the patents serve as a protection against any competitors. Furthermore, Ramani and Kumar (2008, p. 30) show that the normative institutional pressure, the employee reward system and the outsourcing expertise correlate positively with the organizational interaction orientation.

Instead of being satisfied with a subset of opportunities to make relevant offers to customers, it is better for a company to attract or retain customers through a variety of offers (Newell, 2003). Outsourcing increases the ability to provide the demander with a wide range of products and services (King, 2004). 
One can also assume that a superior control of the back-end supply systems increases the interaction response capability (Ramani and Kumar, 2008).

In addition to that, the determinant of the reward system can be linked to the phenomenon of interaction orientation by the sub-construct of customer value management. If information about the individual employee performance exists (i.e. there is a reward system), it is obvious that the company is also able to identify each customer's proportion in the total amount of sales and achievements (meaning it has a corresponding customer value management).

The last examined determinant that correlates positively with the construct of interaction orientation is the normative institutional pressure. Kumar and Ramani acknowledge the positive relationship (to the level of $\alpha=0.05$ ) and thus the assumption that the pressure exerted by competitors measured by the adoption of interactive technologies requires a greater interaction orientation of the company. At a significance level of $1 \%$, this effect is not significantly different from zero.

Lastly, the authors attempt to identify significant differences in the orientation interaction between B2B (business-to-business) and B2C (businessto-consumer) companies. However, the hypothesis that $\mathrm{B} 2 \mathrm{~B}$ companies have a higher degree of interaction orientation than B2C companies had to be clearly rejected (see p-value of 0.46; Ramani and Kumar, 2008). In addition to the antecedents tested by Ramani and Kumar, Danzinger (2010) has identified learning orientation as a determinant of interaction orientation in his work as well.

Regarding the consequences of interaction orientation, Ramani and Kumar firstly distinguish between the aggregated "Customer-Based Relational Performance" (measured for example by customer satisfaction or incurred arising from word-of-mouth) and the aggregated total performance indicator "Customer-Based Profit Performance" (measured by customer loyalty or profitability of demanders). Thereby, interaction orientation has a significant positive effect on both aggregations. Danzinger, however, examines the relationship performance, the overall economic performance and the new product success as consequences of interaction orientation. With the exception of the latter feature, interaction orientation exercises a significant influence on both performance constructs (see Danzinger, 2010, p. 343).

On the one hand, Ramani and Kumar have also tested the competition intensity, which has no significant moderating effect in the relationship between interaction orientation and customer-based relational performance. On the other hand, they have revealed that the customer initiated contacts moderate the positive effect of a firm's interaction orientation on its customer-based relational performance. These contacts are measured by the percentage of 
customers who have communicated with the company that year. According to the authors, if the organization has communicated with many customers, interaction orientation has a greater impact on the aggregated consequences (cf. Ramani and Kumar, 2008, p. 38). Acknowledging these results, Danzinger confirms the non-significant moderating effect of competition intensity. Healso finds a positive effect of firm size, which moderates the relationship between relationship performance and interaction or learning orientation. The degree of solution orientation has a non-significant moderating effect between one strategic orientation and one performance indicator (see Danzinger, 2010, p. 344).

\section{Learning orientation}

In literature on organizational learning, the theoretical considerations are more prevalent than empirical results (cf. Schwaab and Scholz, 2000, p. 354). There are several definitions of learning orientation. For instance, Agryris and Schön (1999, p. 19) define a learning organization as a company that assimilates information (e. g. knowledge, techniques or experiences) in any form. Organizational learning is equated with the identification and correction of errors.

The authors distinguish between three types of learning: Single-loop-, double-loop- and deutero-learning. Single-loop-learning occurs when errors are detected and corrected but the firm carries on with its present policies and goals. Double-loop-learning means that, in addition to singleloop, fundamental issues are questioned and reviewed. However, deuterolearning occurs when organizations "learn to learn". This is very important since the reflecting on the context and the identification of learning barriers and reliefs constitutes an important function (see Argyris and Schön, 1978, p. 26 et seq.).

Furthermore, a distinction must be made between individual and organizational learning. However, theories-in-use exist between the aggregated and individual learning orientation, which can act as a link between these. If the perception of the individual changes, organizational learning can take place. This is successful if the theories are adapted and applied by other persons of the organization. In order to achieve a high level of learning orientation, the creation and application of new theories must become normal since learning should not be seen as a closed process but as a continuous sequence of behavior (Argyris and Schön, 1978, p. 17 et seq.).

In literature there are different conceptualizations of organizational learning. Sinkula, Baker and Noordewier (1997) measure learning orientation as a second-order construct consisting of three dimensions: commitment 
to learning, shared vision and open-mindedness. Calantone, Cavusgil and Zhao (2002) argue that the construct should be complemented by intraorganizational knowledge sharing. However, Perez Lopez, Montes Peon and Vazquez Ordas (2005) use a conceptualization which is heavily based on knowledge generation (see sub-constructs such as acquisition of knowledge, knowledge distribution, organizational memory or knowledge interpretation. Danzinger (2010) combines both approaches and develops the new subconstruct of human resource practices.

Empirical research has identified a great number of determinants of learning orientation, which can be categorized as internal and external antecedents. Company-internal determinants include the organizational structure (cf. Farrell, 1999; Slater and Narver, 1995), the organizational culture (Peng, 2008; Zheng and Cui, 2007; Lee and Tsai, 2005; Grinstein, 2008; Jimenez-Jimenez and Cegarra-Navaroo, 2007) and the organizational strategy (Perez Lopez et al., 2005; Farrell, 2000) while external antecedents consist of the environment where the company operates (Slater and Narver, 1995; Farrell, 1999).

\section{Alternative strategic orientations}

Besides interaction and learning orientation, there are a number of other orientations in literature. Most of them can be summarized under the generic term of "strategic orientation". Neal, West and Patterson (2004) define strategic orientation as the structures, strategies and processes which a company adopts to be able to compete with other organizations in the market. However, all definitions see the strategic orientation as the basis for the firm's strategy.

There are different strategic orientations, but most of the publications only deal with market orientation which specifies the orientation of the business activities on the market. It means the implementation of the marketing concept (see Kohli and Jaworski, 1990) and became the cornerstone of modern marketing ideas (Kirca, Jayachandran and Bearden, 2005). Companies with a high level of market orientation focus all of their activities on the customers' needs and requirements (cf. Utzig, 1997). In literature, two perspectives of market orientation have become established. Firstly, the conceptualization by Narver and Slater (1990) from a corporate culture point of view. Secondly, the definition by Kohli and Jaworski (1990) based on a behavioral view. A large number of variables (for an extract relevant to our model see Table 1) are deemed to be determinants or control variables of interaction orientation, learning orientation or market orientation. 
Table 1. Appearance of the investigated variables in literature

\begin{tabular}{|c|c|c|c|}
\hline \multirow[b]{2}{*}{ Construct } & \multicolumn{3}{|c|}{ Appearance in the Literature of } \\
\hline & $\begin{array}{l}\text { Interaction } \\
\text { Orientation }\end{array}$ & $\begin{array}{c}\text { Learning } \\
\text { Orientation }\end{array}$ & $\begin{array}{c}\text { Market } \\
\text { Orientation }\end{array}$ \\
\hline \multicolumn{4}{|l|}{ Company Characteristics } \\
\hline Distribution & & & $x$ \\
\hline Industry & & $x$ & $x$ \\
\hline Number of Employees & & $x$ & $x$ \\
\hline Sales Previous Year & & & $x$ \\
\hline Type of Operation & $x$ & & $x$ \\
\hline \multicolumn{4}{|l|}{ Employee Characteristics } \\
\hline Age & & $x$ & $x$ \\
\hline Gender & & $x$ & $x$ \\
\hline Tenure & & $x$ & $x$ \\
\hline \multicolumn{4}{|l|}{ Employee Perceptions } \\
\hline Affective Commitment & & $x$ & $x$ \\
\hline Continuance Commitment & & $x$ & $x$ \\
\hline Employee Satisfaction & & $\mathrm{x}$ & $x$ \\
\hline \multicolumn{4}{|l|}{ Environment } \\
\hline Competitive Intensity & $x$ & $x$ & $x$ \\
\hline Market Turbulence & & $x$ & $x$ \\
\hline Normative Institutional Pressure & $x$ & & \\
\hline Technological Turbulence & & $x$ & $x$ \\
\hline \multicolumn{4}{|l|}{ Organizational Culture } \\
\hline Dependence on Trademarks & $x$ & & \\
\hline Learning Orientation & $x$ & & $x$ \\
\hline Willingness to Cannibalize & & & $x$ \\
\hline \multicolumn{4}{|l|}{ Organizational Strategy } \\
\hline Adaptive Selling & & $x$ & $x$ \\
\hline Employee Reward System & $x$ & & \\
\hline Outsourcing Expertise & $x$ & & \\
\hline \multicolumn{4}{|l|}{ Organizational Structures } \\
\hline Formalization & & $x$ & $x$ \\
\hline Interdepartmental Conflicts & & & $x$ \\
\hline Interdepartmental Connectedness & & & $x$ \\
\hline
\end{tabular}

Sources: Chandy and Tellis (1998), Deng and Dart (1994), Dharmadasa (2009), Duff, Boyle, Dunleavy and Ferguson (2004), Farrell and Oczkowski (2002), Farrell (1999), Grinstein (2008), Homburg (2004), Jaworski and Kohli (1993), Kirca et al. (2005), Krohmer (1999), McGuinness and Morgan (2006), Mengüc (1996), Park and Holloway (2003), Ramani and Kumar (2008), Scholderer (2000), Selnes, Jaworski and Kohli (1996), Severiens and ten Dam (1998), Siguaw, Brown and Widing (1994), Siguaw and Honeycut (1995), Steiners (2005) and Verhoef and Leeflang (2009). 
The term "entrepreneurial orientation" describes management attitudes and forms of behavior which are directed towards an innovative business orientation and the pursuit of new company activities. The idea goes back to studies by Miller and Friesen (1978), who have identified eleven dimensions. In addition, they conclude that innovativeness, risk-taking and proactiveness are the central dimensions (Miller, 1983). Each of these sub-constructs can individually exert a positive influence on the company's goals such as adaptability or product innovations. In this study we focus on entrepreneurial proactiveness, which consists in the active pursuit of promising business options and the associated creation of competitive edges (cf. Lumpkin and Dess, 1996).

The customer orientation of salespeople is explained by, for instance, the "customer-oriented selling" (see Saxe and Weitz, 1982) or the "adaptive selling" (Speiro and Weitz, 1990) behavior of salespeople. Adaptive selling is the salesperson's ability to recognize promising attributes of specific selling interactions and adapt their behavior to these (see. Weitz, Sujan and Sujan, 1986, p. 174). This adaptation can take place during the interaction with one customer as well as between the interactions with two different customers. In contrast, customer-oriented selling is defined as "the degree to which salespeople practice the marketing concept to try to help their customers make purchase decisions that will satisfy customer needs" (Saxe and Weitz, 1982, p. 344). Despite the conceptual differences the contents of both constructs are very similar. Table 2 compares these constructs as well as shows differences regarding the contents of these organizational strategies and structures.

Table 2. Overview of the various constructs including differentiation

\begin{tabular}{|c|c|c|c|c|c|c|c|c|}
\hline \multirow[b]{2}{*}{ Construct } & \multirow{2}{*}{$\begin{array}{l}\text { Focus } \\
\text { on cus- } \\
\text { tomer }\end{array}$} & \multirow{2}{*}{$\begin{array}{c}\text { Focus on } \\
\text { organi- } \\
\text { sation }\end{array}$} & \multirow{2}{*}{$\begin{array}{l}\text { Indivi- } \\
\text { duality }\end{array}$} & \multirow{2}{*}{$\begin{array}{l}\text { Relation } \\
\text { to the } \\
\text { customer }\end{array}$} & \multicolumn{4}{|c|}{ Components } \\
\hline & & & & & $\begin{array}{l}\text { compe- } \\
\text { titive }\end{array}$ & $\begin{array}{c}\text { mone- } \\
\text { tary }\end{array}$ & $\begin{array}{l}\text { product- } \\
\text { related }\end{array}$ & social \\
\hline $\begin{array}{l}\text { Adaptive } \\
\text { Selling }\end{array}$ & $X$ & & $\mathrm{x}$ & $\begin{array}{l}\text { with the } \\
\text { client }\end{array}$ & & $x$ & & \\
\hline $\begin{array}{l}\text { Customer-oriented } \\
\text { Selling }\end{array}$ & $\mathrm{x}$ & & $\mathrm{X}$ & $\begin{array}{l}\text { with the } \\
\text { client }\end{array}$ & & $x$ & $X$ & $x$ \\
\hline & & $x$ & & & $\mathrm{x}$ & $x$ & $\mathrm{X}$ & \\
\hline $\begin{array}{l}\text { Interaction } \\
\text { Orientation (IO) }\end{array}$ & $X$ & & $x$ & $\begin{array}{l}\text { with the } \\
\text { client }\end{array}$ & & $x$ & $x$ & \\
\hline $\begin{array}{l}\text { Learning } \\
\text { Orientation (LO) }\end{array}$ & & $x$ & & $\begin{array}{l}\text { for the } \\
\text { client }\end{array}$ & & $x$ & & \\
\hline $\begin{array}{l}\text { Market Orientation } \\
(\mathrm{MO})^{* *}\end{array}$ & $\mathrm{X}$ & $x$ & $x$ & $\begin{array}{l}\text { for the } \\
\text { client }\end{array}$ & $\mathrm{x}$ & & $x$ & \\
\hline
\end{tabular}

* Dimension adopted by Covin and Slevin (1989).

** Definition and conceptualization specified in Kohli and Jaworski (1993).

Knowledge, Participation and Waste Management - Selected Problems, A. Ujwary-Gil (Ed.) 
It can be seen that interaction orientation is the only construct with an individuality focus on the customer which contains a relationship with the customer and monetary as well as product-related components.

\section{Research propositions}

Business-to-business firms organize themselves into account management teams and b2c providers have relations with many similar customers. Ramani and Kumar (2008) hypothesize that b2b firms exhibit a greater degree of interaction orientation than business-to-consumer firms due to a greater acceptance and diffusion of the belief in the customer concept. Organizations in the $\mathrm{b} 2 \mathrm{~b}$ sector rather believe that it is not possible to satisfy each customer with the same products or services and aim to acquire new customers individually rather than business-to-consumer firms. Thus:

H1: Business-to-business firms have a higher interaction orientation than business-to-consumer firms.

Normative pressure derives from the ability to learn from organizations which adopted an innovation through direct or indirect channels. If two firms communicate with each other frequently and directly, the probability of an adapting behavior increases.

Experts make a distinction between stakeholder pressures and competitive pressures. Stakeholder pressures on a firm are exerted by its customers, investors, media, partners or similar shape. Some theorists argue that an organization meets its customers' expectations and requirements because conformity gives it access to the resources it needs to be successful (Di Maggio and Powell, 1991).

Competitive pressures are forces on the firm to adopt a technology or to run the risk of losing competitive edges because of too little customer loyalty and high costs (Abrahamson and Rosenkopf, 1993). Researchers do not agree on whether firms adopt technologies because of institutional pressures from their environments.

Normative institutional pressure relates to the behavior of responding to numerous expectations (Karahanna, Straub and Chervany, 1999). The number of competitive firms that adopt new interactive technologies precipitate the firm's adoption of interactive tools (Wu, Mahajan and Balasubramanian, 2003). Hence,

H2: The greater the normative institutional pressure for a firm, the greater its interaction orientation is.

As, with growing competitive intensity, earnings opportunities of a business unit sink, a firm must encourage customers even more strongly to share opinions of its products with the firm than in a situation with 
low competitive intensity. In addition, the organization will try harder to understand the customers' problems to continue to be successful. So the greater the competitive intensity a firm faces, the greater a firm's customer empowerment and understanding of customer problems would be. Therefore,

H3: The greater the competitive intensity, the greater a firm's interaction orientation would be.

Market turbulence will basically be determined by the fact that the customers' preferences change in the course of time. If they change rapidly, a firm is forced to analyze previous consumer transactions to anticipate future needs and potentials at an early stage, i.e. greater market turbulence results in superior interaction response capacity, the firm's ability to use dynamic database systems and processes. Thus:

H4: The greater the market turbulence, the greater a firm's interaction orientation would be.

There is empirical evidence that the willingness to cannibalize has a positive effect on the number and success of innovations (Chandy and Tellis, 1998). Companies which can easily adapt to requirements that new products involve motivate customers more to express own ideas for new and further developments. Accordingly:

H5: The greater the firm's willingness to cannibalize, the greater its interaction orientation is.

The value creation process firstly is about the acquisition of user knowledge. To achieve this purpose, the company exchanges information with the customer as the carrier of that information. This exchange is an interaction cycle between provider and customer. In addition to the acquisition of knowledge it also is about the adoption of user knowledge (Zahra and George, 2002). During this phase the company tries to anchor the information and make use of it. This change can be seen as an organizational learning process so that this phase can be described as learning orientation. Thus, one could assume that learning orientation requires interaction orientation. However, Arrow's information paradox claims that the value of information (in this case user knowledge) is not known until one already knows the information. But then the information does not have to be acquired anymore (Arrow, 1962).

Suggesting that there is a causal link between the two orientations, it would follow that interactions can only reach their longer-term effect if the companies had a strong organizational learning. So learning orientation would be understood as a precondition of interaction orientation. As far as the relationship between the two strategic orientations is empirically verifiable, its direction should, based on these considerations, be from learning orientation towards interaction orientation. Thus: 
H6: The greater the learning orientation of an organization, the greater its interaction orientation is.

If the employees at the company are older, i.e. they have gained more experience in their profession, they probably have a higher competence. Consequently, they can offer the company advanced knowledge about the firm's idea of what each individual customer has contributed to its profits and provide better predictions (i.e. they will allow for a better customer relationship management). Accordingly:

H7: The older the employees are, the greater the firm's interaction orientation.

Companies such as huge banks forming part of the financial industry can match each transaction (e.g. money transfer or debit entry) with a single customer because of individual account management. Equally the employees must have the opportunity to get access to customer information at any time so that they can give individual advice to the customer independently.

Furthermore, there are a lot of opportunities for consumers to interact with the bank, e.g. by appropriate applications for payment transactions in smart- or i-phones. Though customers in the financial industry are individual rather than organizational customers (that means these companies are primarily B2C focused), the extent of higher interaction response capacity allows for the following thesis:

H8: Financial firms exhibit a greater degree of interaction orientation than companies in other industries.

Firms with a high level of interaction orientation encourage customers to participate in designing products and services (Ramani and Kumar, 2008). Ideas for innovations can be generated from this interaction process and it is known that innovations arise in interfaces between customers and organizations (Pirinen and Fränti, 2008). Hence,

H9: The greater the firm's interaction orientation, the more product innovations are generated by the firm.

The construct of entering new markets describes the start of a new business within an existing organization such as the establishment of a new business unit. If the firm encourages customers to participate interactively in designing new products, which means that the firm has a high level of interaction orientation, the company will be able to offer significantly more products or services to pursue new business. Thus:

$\mathrm{H} 10$ : The greater the firm's interaction orientation, the more the firm is engaged in entering new markets.

The firm's adaptability refers to the ability of the company to adapt to any environmental changes (see Rueckert, Walker and Roering, 1985). For example, this ability implies the adaption of the products to the changing 
needs of customers and quick reaction to new threats in the market (Irving, 1995). The implementation of these measures implies a high level of interaction orientation, e. g. by an understanding of the customers' problems or by customer empowerment to collaborate in new or further product developments. This argumentation leads us to the below hypothesis:

H11: The greater the interaction orientation of a firm, the greater the firm's adaptability is.

The firm's effectiveness can be operationalized by parameters such as achieving the degree of customer satisfaction, reaching the target market share or acquiring new customers (Irving, 1995; Rueckert et al., 1985). A higher degree of interaction response capacity and customer empowerment results in a higher level of customer satisfaction (Ramani and Kumar, 2008, p. 29). Through the customer empowerment, which lets the customer take part in the ongoing development of products, the company can respond to the customers' needs in a better way, which creates competitive edges (see Kohli and Jaworski, 1990). These considerations justify the following hypothesis:

H12: The greater the interaction orientation of a firm, the greater the firm's effectiveness is.

Customer-specific success refers to parameters like customer retention, achieving authenticity or minimizing customer complaints. We can say that the aim of interaction orientation is towards the understanding of the customer's problem. The arrangement of interaction is represented by the behavior of customer contact staff, where customer satisfaction and trusting customer relationships are primary goals. A high degree of interaction orientation includes a great understanding of customer problems, which leads to increased success (Danzinger, 2010). Accordingly:

H13: The greater the interaction orientation of a firm, the greater the firm's customer-specific success is.

It is known from literature that market orientation and entrepreneurial orientation have synergetic effects on the product innovation activities and performance (Atuahene-Gima and Ko, 2001). Furthermore, Baker and Sinkula (1999b) find a synergetic effect of market orientation and learning orientation, showing that they both combine positively to impact the change in relative market share. In addition, they identify a synergistic effect of market orientation and learning orientation on new product success. This is why we assume that there are positive or negative synergetic effects of market orientation and interaction orientation on suitable constructs, too.

Firms that combine high levels of interaction and market orientation should perform better in consequence in effectiveness or customer-specific success than other combinations of both orientations. Since firms with lower market orientation might have an inflexible structure of interaction 
orientation, we also argue that the greater the organization's market orientation, the stronger the positive relationship between its interaction orientation and effectiveness or success is. Therefore:

H14: There are synergetic effects of interaction orientation and market orientation on effectiveness.

H15: There are synergetic effects of interaction orientation and market orientation on customer-specific success.

\section{Data and measures}

We have derived data from structured questionnaires drawn from a random sample of people who are occupied with selling and enter into direct contact with customers. The surveys are also checked for obvious instances of incompleteness and yes-saying. This process eliminates less than $2 \%$ of the sample. The final sample consists of 231 participants, who have answered a total of 165 questions.

Most of our measures have been used in past research and consist of items on a seven point Likert scale with the response items ranging from 1 (= "applies completely") to 7 (="doesn't apply at all"). Number of employees (variable: employees; $1=$ "> 100"), sales previous year (sales; $1=$ "> EUR 10 million"), type of operation (b2b; 1 = "business-to-business", $0=$ "businessto-consumer"), gender (sex; 1 = "man") and distribution (sphere; 1 = "(inter) national", $0=$ "local") are binary just as the industry variables energy ( 1 = "company is a energy firm") and finance ( $1=$ "company is a financial services firm"), which are based on the latest NACE Codes using the NACE Revision 2 Classification (Eurostat, 2008). Tenure and age are measured in years.

We have adapted the scales of interaction orientation from Ramani and Kumar (2008), consisting of four dimensions relating to the firm's belief in the customer concept, the interaction response capacity, the customer empowerment and the customer value management. Furthermore, we also developed another sub-construct as some explorative interviews have indicated that the understanding for the customer problem is a central aspect of interaction's success of the company (Danzinger, 2010, p. 145). In addition, we developed some new items to measure normative institutional pressure (normative3), outsourcing expertise (outsource3) and dependence on trademarks (trademarks3).

Learning orientation is operationalized by the scales from Sinkula et al. (1997) and Jerez-Gomez (2005). The interviews have revealed clearly that learning orientation without human resources practices is not completely defined. Therefore we add that construct as another dimension of learning 
orientation, so it consists of four sub-constructs: experimentation and openness, learning commitment, shared vision and human resources practices. The measure of market orientation is adopted from the original MKTOR scale (see Narver and Slater, 1990). For proactiveness (PRO), we use the items developed by Venkatraman (1989).

One part of the measures in Figure 1 is taken from Ramani and Kumar (2008), who include them as determinants of interaction orientation. This figure also shows that the other hypothetical antecedents have been tested to be determinants of organizational learning or market orientation. That is certainly the case for the consequences of interaction orientation, which are formerly verified consequences of market or learning orientation. With regard to the formulated hypotheses and presented determinants the following model is constructed:

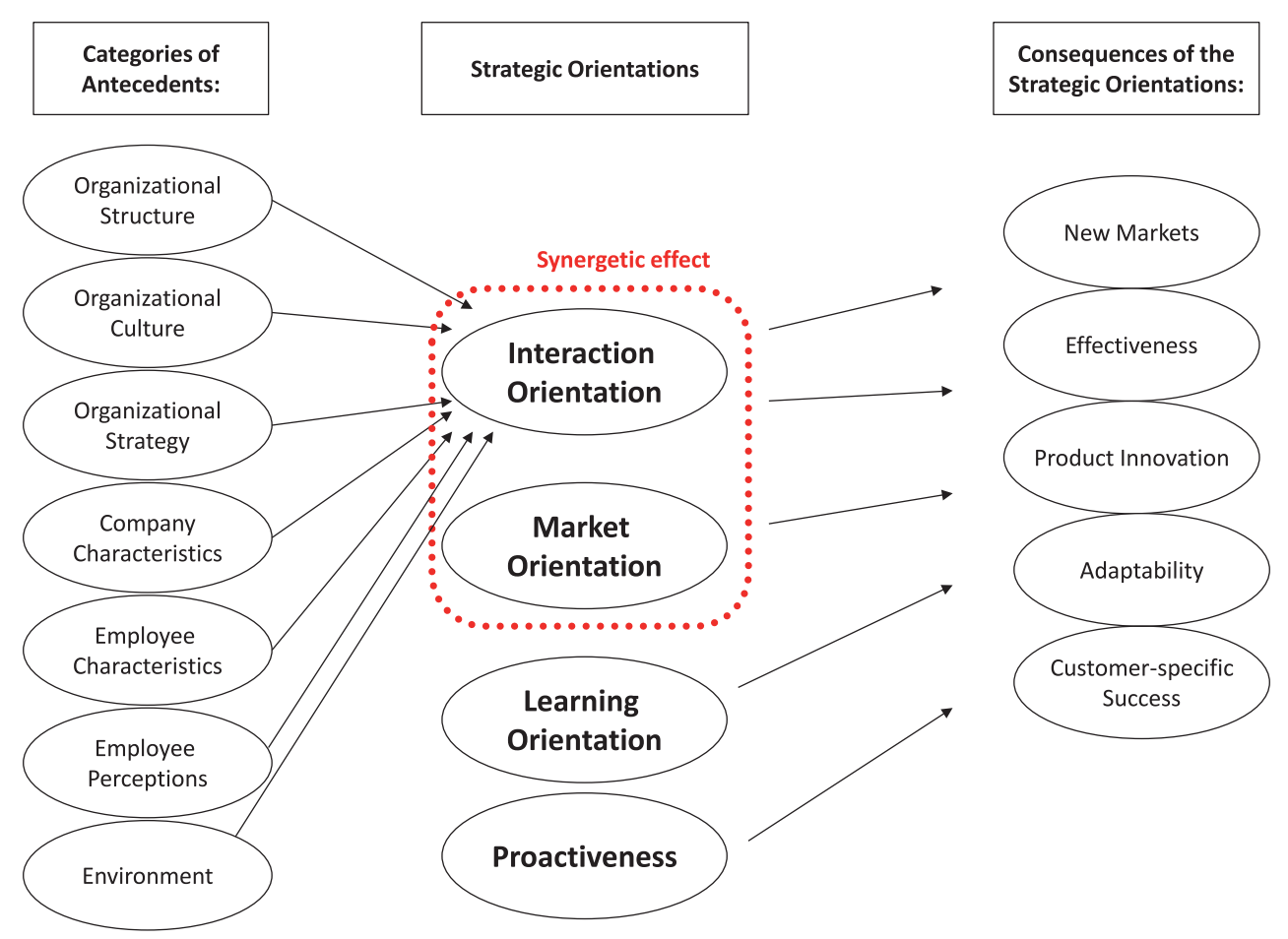

Figure 2. The hypothesized model

\section{Method}

We carry out a confirmatory factor analysis to extract the factors to confirm the validity of our new sub-construct understanding customer problems (ucp) as a part of the latent variable interaction orientation. Thus, we investigate our questionnaire to check if it correctly determines the proposed substructure. Initially the internal consistency of the grouped questions is studied by Cronbach's alpha for our sample. Each construct has an alpha greater than 
0.7 , so the data has an acceptable degree of reliability. As extraction method for the subsequent factor analysis we use principal components and a varimax rotation of the loadings. For the discriminant validity of the factor analysis we claim the difference of the loadings of one item on different factors to be less than 0.2 (Nunnally and Bernstein, 1994). For convergent validity the relevant loadings should be greater than 0.4 (Anderson and Gerbing, 1988; Chen, Paulraj and Lado, 2008).

Linear relationship between interaction orientation and its determinants is assumed. We identify the crucial effects on interaction orientation by a linear regression model. Since we observe several outliers in our data set, we eliminate extreme observations. We exclude respondents exhibiting a Cook's distance that exceeds the conventional threshold 4/(n-k-1), where $n$ denotes the sample size and $k$ the number of covariates (Fox, 1997, p. 281). Another linear model is applied to determine the effect of interaction orientation, learning orientation, market orientation and proactiveness to the above mentioned consequences. In this case, we do not delete outliers for each model for the sake of comparability. In either regression we check for multicollinearity by the variance inflation factor. All analysis are carried out using SPSS 19 and R 2.7.

\section{Descriptive statistics}

Our data set comprises 231 cases whereof 133 questionnaires have been answered by male and 98 by female interviewees. The mean age of the respondents is $34(\mathrm{~s} d=11.39)$, with a minimum of 20 and a maximum of 63 years, hence covering the range of relevant age. We distinguish between several industries. The boxplots in Figure 3 illustrate the impact of the sector on interaction orientation. We hypothesize that companies in the financial sector are affected to interaction orientation to a greater extent than any other line of business. This hypothesis is encouraged by Figure 2 showing that financial services features the smallest median of all industries and that $25 \%$ of all companies in this industry have a value between 1.94 and 2.38 for the aggregated interaction orientation item. 


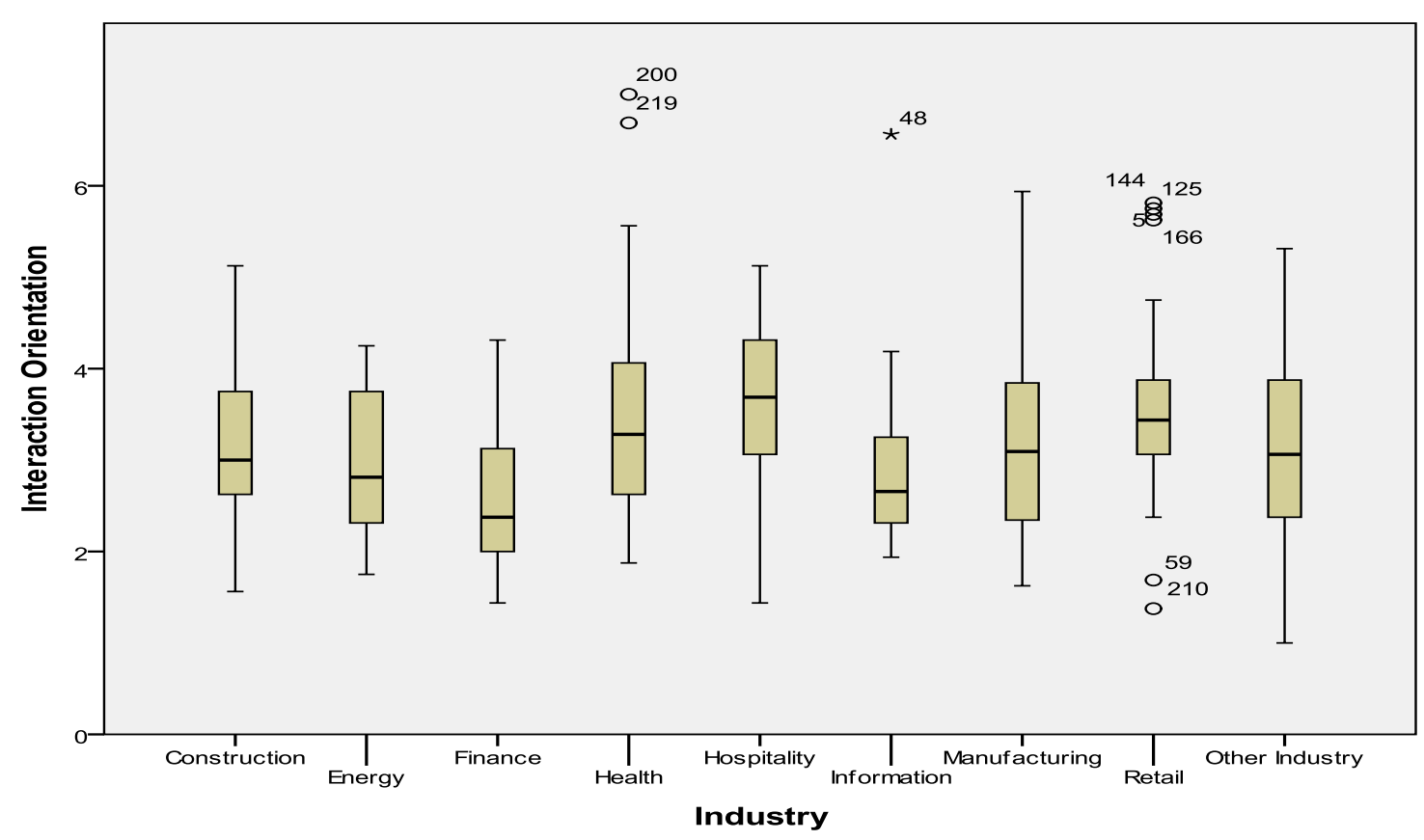

Figure 2. Box plots for interaction orientation separated by industrial sector

Also, the energy sector reveals an above average interaction orientation. This may be due to the fact that it is mainly business-to-business (cf. Table 3). Furthermore, we see that in our sample the financial business sector is mostly business-to-client. Also, firms that deal mainly with private customers dominate the sectors hospitality, retail and health while companies that primarily serve business clients are of the production segment. The remaining business areas are well-balanced.

Table 3. Contingency table for customer type, averaged strategic orientation and industry

\begin{tabular}{lccccccccc}
\hline & $\begin{array}{c}\text { Constr- } \\
\text { uction }\end{array}$ & Energy & Finance & Health & $\begin{array}{c}\text { Hospi- } \\
\text { tality }\end{array}$ & $\begin{array}{c}\text { Infor- } \\
\text { mation }\end{array}$ & $\begin{array}{c}\text { Manu- } \\
\text { facturing }\end{array}$ & Retail & Other \\
\hline B2B & $47 \%$ & $69 \%$ & $4 \%$ & $13 \%$ & $6 \%$ & $53 \%$ & $61 \%$ & $23 \%$ & $51 \%$ \\
IO & 3.12 & 2.94 & 2.62 & 3.59 & 3.60 & 2.98 & 3.29 & 3.55 & 3.13 \\
LO & 3.32 & 2.92 & 2.77 & 3.17 & 3.95 & 3.11 & 3.27 & 3.32 & 3.18 \\
MO & 3.29 & 3.24 & 2.96 & 3.60 & 3.31 & 3.18 & 3.47 & 3.39 & 3.33 \\
PRO & 4.24 & 3.75 & 4.02 & 4.25 & 4.48 & 3.83 & 4.39 & 4.13 & 3.99 \\
\hline
\end{tabular}

\section{Factor analysis}

We run the factor analysis involving relevant items for the latent construct of interaction orientation. The Kaiser-Meyer-Olkin criterion suggests good sampling adequacy $(\mathrm{KMO}=0.858)$. All observed communalities are greater 
than the usual threshold of 0.3 , lying between the minimum of 0.535 and the maximum of 0.818 . The eigenvalue criterion recommends picking the factors with an eigenvalue greater than 1 . In our case we therefore obtain five factors. The fraction of the variance conserved by these extracted components is $70 \%$, which indicates a good explanatory power of the factors. All extracted and rotated factors explain more than 10 percent of the variance each, with a maximum of nearly $19 \%$ for factor 2 . We can assign each factor to one of the intended sub-constructs of customer management value, customer empowerment, understanding customer problems, interaction response capacity and belief in the customer concept. For example we can interpret factor 1 as a customer management value since only items $\mathrm{crm} 1$ to $\mathrm{crm} 3$ exhibit a substantial loading on this factor (see Table 4). All relevant loadings are greater than 0.4 . The item ucp2 does not have acceptable discriminative power as it reveals a high loading both on the ce and ucp factors. By contrast, we can see that the new items uсp3 and ucp4 differentiate more clearly.

Our findings implicate that indeed a fifth dimension understanding customer problems of interaction orientation exists. For future studies we recommend to evolve a new item ucp2, since it lacks discriminative power. Note that the loading of the item ucp3 is highly negative, because it is a reverse item.

Table 4. Extracted factors and rotated factor loadings

\begin{tabular}{lccccc}
\hline Item & Factor $\mathbf{1}$ & Factor $\mathbf{2}$ & Factor $\mathbf{3}$ & Factor $\mathbf{4}$ & Factor 5 \\
\hline cvm1 & $\mathbf{0 . 7 9 8}$ & 0.094 & 0.166 & 0.234 & 0.115 \\
cvm2 & $\mathbf{0 . 8 5 8}$ & 0.116 & 0.029 & 0.225 & 0.088 \\
cvm3 & $\mathbf{0 . 8 6 7}$ & 0.099 & 0.048 & 0.113 & 0.146 \\
ce1 & 0.140 & $\mathbf{0 . 7 4 8}$ & 0.166 & 0.242 & -0.100 \\
ce2 & 0.082 & $\mathbf{0 . 7 8 5}$ & -0.012 & 0.188 & 0.065 \\
ce3 & 0.115 & $\mathbf{0 . 8 7 8}$ & 0.109 & 0.052 & 0.113 \\
ce4 & 0.015 & $\mathbf{0 . 8 5 0}$ & 0.114 & 0.035 & 0.172 \\
ucp1 & 0.210 & 0.410 & $\mathbf{0 . 6 2 7}$ & 0.161 & 0.276 \\
ucp2 & 0.234 & 0.438 & $\mathbf{0 . 5 6 3}$ & 0.051 & 0.148 \\
ucp3 & 0.039 & 0.164 & $-\mathbf{0 . 8 2 2}$ & -0.111 & 0.123 \\
ucp4 & 0.078 & 0.263 & $\mathbf{0 . 6 0 7}$ & 0.074 & 0.292 \\
irc1 & 0.123 & 0.229 & 0.055 & $\mathbf{0 . 7 8 2}$ & 0.052 \\
irc2 & 0.166 & 0.143 & 0.132 & $\mathbf{0 . 8 6 5}$ & 0.061 \\
irc3 & 0.335 & 0.310 & 0.066 & $\mathbf{0 . 6 0 4}$ & 0.344 \\
irc4 & 0.174 & -0.035 & 0.095 & $\mathbf{0 . 7 6 7}$ & 0.199 \\
cc1 & 0.041 & -0.024 & -0.038 & 0.066 & $\mathbf{0 . 8 1 6}$ \\
cc2 & 0.164 & 0.183 & 0.293 & 0.352 & $\mathbf{0 . 5 8 4}$ \\
cc3 & 0.275 & 0.187 & 0.222 & 0.187 & $\mathbf{0 . 6 5 2}$ \\
\hline
\end{tabular}




\section{Reliability and validity}

For the subsequent analysis we examine the reliability of our items by Cronbach's alpha and Item-To-Total-correlations. For the former we impose a threshold of 0.7 , and in case of a lower alpha-value we choose a subset of items for each group satisfying the restriction. The Fornell-Larcker-Criterion requires that the average variance extracted of the constructs should be greater than the square of the correlations among the constructs (Fornell and Larcker, 1981). This condition has been met and all items have high factor loadings, so discriminant and convergent validity are proved.

\section{Determinants of interaction orientation}

Now we perform a regression analysis to identify the determinants of interaction orientation. As predictors we introduce a lot of variables (see Measures). With a first regression we compute Cook's distance for each observation. The histogram of all distances in Figure 3 suggests to eliminate observations that show a Cook's $D$ greater than 0.02 , which is consistent with the threshold of $4 /(n-k-1)=0.019$ which we use here. In doing so, 216 observations remain.

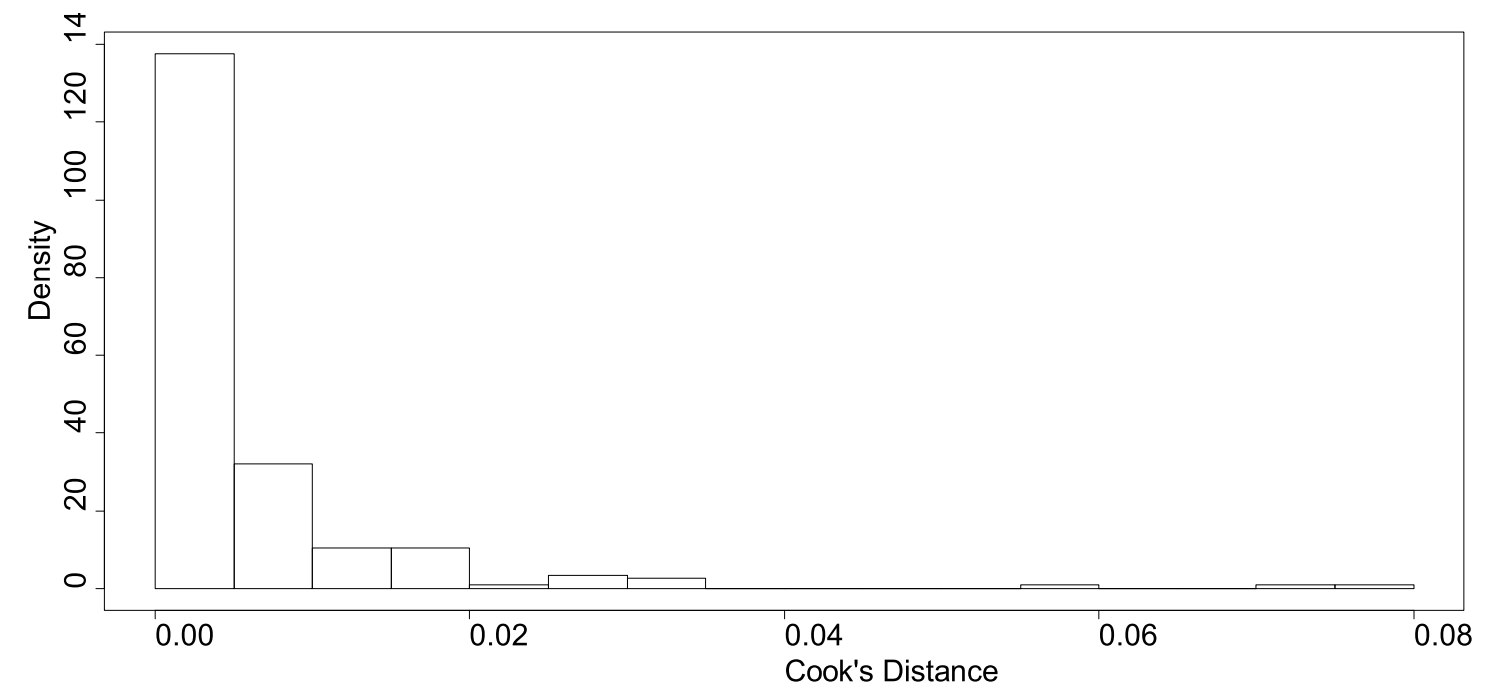

Figure 3. Histogram of Cook's distances

The fit of the regression model is very promising $\left(R^{2}=0.694\right.$, and $F=17.314$, $p=0.000)$. The resulting parameter estimates, errors, standardized estimates and $p$-values are given in Table 5. Also, tolerance values and variance inflation factors are reported. None of the latter exceeds 10 so that obviously we do not face multicollinearity issues (see Belsley et al., 1980, p. 93). 
Table 5. Results of the regression on interaction orientation

\begin{tabular}{|c|c|c|c|c|c|}
\hline Variable & Coefficient & Sd & Std. Coeff. & p-Value & VIF \\
\hline constant & 0.238 & 0.591 & & 0.688 & \\
\hline B2B & -0.384 & 0.103 & -0.179 & 0.000 & 1.442 \\
\hline LO & 0.418 & 0.057 & 0.465 & 0.000 & 2.508 \\
\hline reward & -0.011 & 0.032 & -0.016 & 0.738 & 1.504 \\
\hline trademarks & -0.036 & 0.031 & -0.060 & 0.243 & 1.633 \\
\hline outsource & 0.018 & 0.031 & 0.027 & 0.550 & 1.253 \\
\hline normative & 0.075 & 0.038 & 0.109 & 0.050 & 1.903 \\
\hline affective & 0.019 & 0.051 & 0.023 & 0.707 & 2.426 \\
\hline continuance & -0.091 & 0.049 & -0.084 & 0.063 & 1.271 \\
\hline satisfaction & 0.040 & 0.069 & 0.038 & 0.561 & 2.632 \\
\hline conflicts & -0.049 & 0.037 & -0.059 & 0.181 & 1.200 \\
\hline connectedness & -0.048 & 0.048 & -0.047 & 0.319 & 1.405 \\
\hline adaptive & 0.079 & 0.049 & 0.077 & 0.112 & 1.470 \\
\hline technoturbu & 0.033 & 0.031 & 0.054 & 0.293 & 1.653 \\
\hline competitive & 0.109 & 0.038 & 0.137 & 0.005 & 1.421 \\
\hline marketturbu & 0.126 & 0.050 & 0.126 & 0.013 & 1.578 \\
\hline cannibalize & 0.175 & 0.041 & 0.226 & 0.000 & 1.767 \\
\hline formalization & -0.047 & 0.033 & -0.065 & 0.156 & 1.284 \\
\hline employees & 0.015 & 0.130 & 0.007 & 0.909 & 2.559 \\
\hline sales & 0.092 & 0.139 & 0.046 & 0.509 & 2.951 \\
\hline sphere & 0.142 & 0.105 & 0.070 & 0.179 & 1.671 \\
\hline tenure & -0.001 & 0.008 & -0.010 & 0.867 & 2.131 \\
\hline finance & -0.533 & 0.154 & -0.157 & 0.001 & 1.280 \\
\hline energy & -0.093 & 0.183 & -0.022 & 0.613 & 1.160 \\
\hline sex & 0.042 & 0.089 & 0.020 & 0.640 & 1.196 \\
\hline age & 0.011 & 0.005 & 0.118 & 0.044 & 2.113 \\
\hline
\end{tabular}

Significant effects (at the level of 0.05) can be observed for the variables $B 2 B, L O$, normative, continuance, competitive, marketturbu, cannibalize, finance and age. The assumption of a high interaction orientation in financial services is supported by the results whereas the energy sector does not have a significant effect since it is mainly B2B. Learning orientation has obviously the highest absolute standardized estimate and thus a large impact on interaction orientation. This is most likely due to the fact that both are strategic orientations. Although we expected continuance to have a positive effect, it appears to be negative. In fact, continuance is correlated with affective since both are commitments, thus the exclusion of either of them could change the indication. The variable trademarks confirms the result of Ramani and Kumar (2008), although the effect is not significant. A variable selection could possibly lead to significant results. 
Separate regressions for different groups of covariates reveal which group conserves most of the variance of interaction orientation by means of the model's $R^{2}$. In this regard, the organizational culture strongly influences interaction orientation. Also the environment and employee perception are good indicators. Organizational structure and employee characteristics seem to be less important. The observations above show that age does have a significant influence, nevertheless we see here that experience does not sufficiently state interaction orientation.

Table $6 . R^{2}$ by group of determinants

\begin{tabular}{lcc}
\hline Group & $\mathbf{R}^{\mathbf{2}}$ & Adjusted $\mathbf{R}^{\mathbf{2}}$ \\
\hline Company Characteristics & 0.170 & 0.146 \\
Employee Characteristics & 0.041 & 0.027 \\
Employee Perception & 0.202 & 0.190 \\
Environment & 0.280 & 0.266 \\
Organizational Culture & 0.608 & 0.602 \\
Organizational Strategy & 0.169 & 0.157 \\
Organizational Structure & 0.063 & 0.049 \\
\hline
\end{tabular}

\section{Consequences of interaction orientation}

Now we investigate the consequences of interaction orientation, learning orientation, market orientation and proactiveness as a dimension of entrepreneurial orientation. Interaction orientation appears not to influence adaptiveness, entering new markets or product innovation (see Table 7). However, a significant effect on customer-specific success and effectiveness can be observed. All $p$-values are rather small so that an augmentation of the sample size could lead to significant results. Furthermore, we see that innovation requires a proactive attitude and also the opening of new markets is mainly influenced by proactiveness and market orientation. The results indicate that high adaptiveness arises from proactiveness, market and learning orientation whereas proactiveness is less important for customer-specific success and effectiveness. The latter is influenced significantly by market orientation and interaction orientation. Hence, learning orientation does not have an impact on effectiveness as it has on customer-specific success, just like market and interaction orientation. We conclude that market orientation still is an important factor. The estimation of the interaction effect between interaction orientation and market orientation does not yield significant results. For the other regressions we did not estimate the interaction effects since the main effects are not significant. 


\section{Verification of hypotheses}

Now we examine the validity of our hypotheses. To begin with we examine $\mathrm{H} 1$, which claims that business-to-business firms have a higher interaction orientation than business-to-consumer firms. This hypothesis is clearly supported by the regression (refer to Table 4). The significant parameter estimate of $-0.384(P<0.001)$ is negative, thus indicating the validity of hypothesis 1 . Also, our regression affirms $\mathrm{H} 2$. The estimate related to normative institutional pressure is $0.075(\mathrm{P}=0.050)$ so that an increase in this item causes a rise in interaction orientation. Therefore, our findings verify hypothesis 2 . Competitive intensity also features a positive estimate in our regression model 2 (estimate $0.109, \mathrm{P}=0.005$ ) and thus we can approve $\mathrm{H} 3$ since this indicates a positive influence of competitive intensity on interaction orientation. Hypothesis $\mathrm{H} 4$ states that the greater the market turbulence, the greater a firm's interaction orientation. The corresponding parameter estimate of $0.126(P=0.013)$ is consistent with this statement. The next hypothesis $\mathrm{H} 5$ argues that the firm's willingness to cannibalize supports its interaction orientation. Since our estimate for the cannibalization effect is significantly positive (estimate $0.175, \mathrm{P}<0.001$ ) this conjecture proves to be true. The finding that the estimated effect of learning orientation is statistically significant and positive $(0.418, \mathrm{P}<0.001)$ indicates, furthermore, that $\mathrm{H} 6$ is true. This determinant is more important than the others, because the standardized coefficient has the greatest impact on interaction orientation.

Table 7. Regression coefficients and $p$-values for the consequences

\begin{tabular}{lccccc}
\hline Variable & $\begin{array}{c}\text { Product } \\
\text { Innovation }\end{array}$ & $\begin{array}{c}\text { Entering } \\
\text { New Markets }\end{array}$ & Effectiveness & $\begin{array}{c}\text { Customer-spe- } \\
\text { cific Success }\end{array}$ & Adaptiveness \\
\hline constant & $-0.614(0.114)$ & $-0.311(0.424)$ & $0.003(0.995)$ & $0.111(0.828)$ & $-0.582(0.063)$ \\
IO & $0.186(0.086)$ & $0.154(0.157)$ & $0.335(0.031)$ & $0.316(0.042)$ & $0.155(0.186)$ \\
LO & $-0.001(0.989)$ & $0.059(0.551)$ & $0.256(0.090)$ & $0.360(0.017)$ & $0.159(0.045)$ \\
MO & $0.182(0.106)$ & $0.244(0.031)$ & $0.282(0.001)$ & $0.352(0.000)$ & $0.326(0.000)$ \\
PRO & $0.863(0.000)$ & $0.653(0.000)$ & $0.045(0.550)$ & $-0.087(0.251)$ & $0.496(0.000)$ \\
IO x MO & & & $-0.027(0.464)$ & $-0.035(0.346)$ & \\
$\mathrm{R}^{2}$ (Adj.) & $0.411(0.401)$ & $0.355(0.343)$ & $0.363(0.348)$ & $0.392(0.379)$ & $0.461(0.452)$ \\
\hline
\end{tabular}

The estimated parameter for employees' age is also statistically significant and positive $(0.011, \mathrm{P}=0.044)$ so that older employees offer a higher interaction orientation than their younger colleagues (H7). As we have seen before, financial firms exhibit a greater degree of interaction orientation than companies in other industries (H8). This result is supported by the boxplots in Figure 3 as well as by the parameter estimate in the regression model, which is $-0.533(P=0.001)$

Now we look at the hypotheses regarding the consequences of interaction orientation. Hypothesis H9 claims that the greater the firm's 
interaction orientation, the more product innovations are generated. This can be affirmed by the positive estimate $(0.186, \mathrm{P}=0.086)$. Also we conclude that the firm's interaction orientation enhances the commitment to opening up new market (H10). This is supported by the estimated parameter value of $0.154(P=0.157)$. In addition, the impact of interaction orientation on the adaptiveness $(\mathrm{H} 11)$ is verified by the parameter estimate of our regression model $(0.155, \mathrm{P}=0.186)$. Also effectiveness $(0.335, \mathrm{P}=0.031)$ and customer specific success are achieved by interaction orientation ( $\mathrm{H} 12$ and $\mathrm{H} 13)$. However, the last two hypotheses $\mathrm{H} 14$ and $\mathrm{H} 15$ are not substantiated by our results since both interaction effects do not turn out to be statistically significant.

\section{Discussion and conclusion}

The results of our study reveal operative recommendations for companies. Interaction orientation is a crucial factor for the fulfillment of business objectives. The business culture turns out to be an essential determinant of interaction orientation. Furthermore, companies should be willing to cannibalize and provide a distinct learning orientation. Indeed, organizational learning is of particular importance, that is to say not only should the companies pursue single-loop or double-loop learning but rather Deutero learning, i.e. they should learn to learn. Market Orientation, interaction orientation and learning orientation can increase business success whereas learning is not of importance for business efficiency. Older and thus generally more experienced employees offer a superior interaction orientation and should therefore be recruited preferably. Nevertheless, the work experience is not a sufficient indicator for interaction orientation. This paper shows that business-to-business firms have a greater interaction orientation than business-to-consumer firms. Companies in the energy industry achieve the highest level of proactiveness, whereas financial services are strongly oriented to interaction, learning and market. The health and hospitality sectors have a very weak level of strategic orientation. In addition, the orientation is influenced by the environment. Thus, industries with a high level of competitive intensity and market turbulence tend to show distinct interaction and market orientation.

The greater the strategic orientation of a firm, the greater the firm's adaptability, effectiveness and customer-specific success. Furthermore, such companies are able to be more engaged in entering new markets. However, innovations first require a high degree of proactive attitude.

In contrast to adaptive selling, interaction orientation is more productrelated. The term focuses on the individual customer and usually a mutual 
relationship will develop during this interaction. This orientation has monetary elements, but neither competitive nor social components. We see that indeed a fifth dimension of interaction orientation exists.

A challenge for further research is the reconstruction of our sub-construct understanding customer problems. Differentiation between business-tobusiness and business-to-customer is not satisfactory and should be refined to an industry configuration. The business environment is worth being explored more deeply since three items of this group have a significant impact on interaction orientation. The results of our study question the existence of synergetic effects between market orientation and learning orientation.

Possibly a panel survey could elaborate the findings of our crosssectional study. Also, it could be helpful to have multiple respondents of the same company to avoid single-informant bias. Increasing the sample size could lead to more significant results and an international survey could help to generalize our results. Furthermore, the influence of national cultures can be examined. It should be considered whether individualism or small power distance result in a higher degree of interaction orientation.

In our work we adopted the construct of market orientation by Narver and Slater (1990), another option is the design by Kohli and Jaworski (1990) which could be examined in another survey. In our study we did not perform any variable selection technique since we did not find any evidence for multicollinearity. Thereby, we were able to present an overview of all effects. Omitting the insignificant items could potentially lead to slightly different estimates and $p$-values, maybe even some of the insignificant effects turn out to be significant after all. Not only proactiveness but also the complete construct entrepreneurship orientation could serve as determinant of the business performance. Several variables like market and technological turbulences or absorptive capacity are known to have moderator effects on strategic orientations and could be the objective of further research. We also think of group wise regressions on interaction orientation for a better understanding of the effects and to avoid possible problems of correlated covariates.

From the implications of our research we conclude that interaction orientation is relevant in every market environment. Firms should focus on building an interaction orientation, regardless of whether they have a higher degree of learning or market orientation. 


\section{References}

Abrahamson, E., Rosenkopf, L. (1993). Institutional and competitive bandwagons: Using mathematical modeling as a tool to explore innovation diffusion. Academy of Management Review, 18(3), 487-517.

Anderson, J. C., Gerbing, D. W. (1988). Structural equation modeling in practice: A review and recommended two-step approach. Psychological Bulletin, 103(3), 411-423.

Argyris, C., Schön, D. (1999) Organizational Learning II, Addison-Wesley, Reading.

Arrow, K. J. (1962). Economic Welfare and the Allocation of Ressources for Invention. In: Nelson, R. R. (Ed.), The Rate and Direction of Inventive Activity: Economic and Social Factors. UMI: New York, 609-625.

Atuahene-Gima, K., Ko, A. (2001). An empirical investigation of the effect of market orientation and entrepreneurship orientation alignment on product innovation. Organization Science, 12, 54-74.

Baker, M. J., Sinkula, J. M. (1999a). Learning orientation, market orientation, and innovation: Integrating and extending models of organizational performance. Journal of Market Focused Management, 4, 295-308.

Baker, M. J., Sinkula, J. M. (1999b). The synergistic effect of market orientation and learning orientation on organizational performance. Journal of the Academy of Marketing Science, 27(4), 411-427.

Belsley, D. A., Kuh, E., Welsch, R. E. (1980) Regression Diagnostics: Identifying influential data and sources of collinearity. John Wiley: New York.

Buckler, F. (2003). NEUSREL: Mit Neuronalen Netzen kausale Zusammenhänge aufdecken und verständlich darstellen'. In: Wiedmann, K.-P., Buckler, F. (Eds.), Neuronale Netze im Marketing-Management. Gabler: Wiesbaden.

Calantone, R. J., Cavusgil, S. T., Zhao, Y. (2002). Learning orientation, firm innovation capability, and firm performance. Industrial Marketing Management, 31, 515-524.

Chandy, R. K.,Tellis, G. J. (1998). Organizing for radical product innovation: The overlooked role of willingness to cannibalize. Journal of Marketing Research, 35(4), 474-487.

Chen, I. J., Paulraj, A., Lado, A. (2008). Strategic purchasing, supply management, and firm performance. Journal of Operations Management, 22(5), 505-523.

Covin, J. G., Slevin, D. P. (1989). Strategic management of small firms in hostile and benign environments. Strategic Management Journal, 10(1), 75-87.

Danzinger, F. (2010) Kundeninteraktionskompetenz in Industriegütermärkten: Eine empirische Studie zur Interaktions- und Lernorientierung. Gabler: Wiesbaden.

Deng, S., Dart, J. (1994).. Measuring market orientation: A multi-factor, multiitem approach. Journal of Marketing Management, 10, 725-742. 
Dharmadasa, P. (2009) Organisational Learning, Innovation and Performance in Family-Controlled Manufacturing Small and Medium-Sized Enterprises (SMEs) in Australia. Dissertation: Bond University.

Duff, A., Boyle, E., Dunleavy, K., Ferguson, J. (2004). The relationship between personality, approach to learning and academic performance. Personality and Individual Differences, 36, 1907-1920.

Eurostat (2008). NACE Revision 2: Statistical Classification of Economic Activities'. Retrieved from: http://epp.eurostat.ec.europa.eu (Accessed 20th Dezember 2011).

Farrell, M. A. (1999). Antecedents and consequences of a learning orientation. Marketing Bulletin, 10, 38-51.

Farrell, M. A. (2000). Developing a market-oriented learning organisation. Australian Journal of Management, 25(2), 201-222.

Farrell, M. A., Oczkowski, E. (2002). Are market orientation and learning orientation necessary for superior organizational performance? Journal of Market-Focused Management, 5, 197-217.

Fornell, C., Larcker, D. F. (1981). Evaluating Structural equation models with unobservable variables and measurement error. Journal of Marketing Research, 18(1), 39-50.

Fox, J. (1997) Applied regression analysis, linear models, and related methods. Sage: Thousand Oaks.

Grinstein, A. (2008). The relationships between market orientation and alternative strategic orientations: A meta-analysis. European Journal of Marketing, 42(1), 115-134.

Homans, G. C. (1951). The Human Group, Harcourt: Brace \& World, New York.

Homburg,C.(2004)Perspektiven dermarktorientierten Unternehmensführung . Gabler: Wiesbaden.

Hult, G. T. M., Hurley, R. F., Knight, G. A. (2004). Innovativeness: Its antecedents and impact on Business Performance. Industrial Marketing Management, 33, 429-438.

Irving, E. (1995) Marketing Quality Practices, Dissertation, University of North Carolina.

Jaworski, B. J., Kohli, A. K. (1993). Market orientation: antecedents and consequences. Journal of Marketing, 57(3), 53-70.

Jerez-Gomez, P. (2005). Organizational learning capability: a proposal of measurement. Journal of Business Research, 58(6), 715-725.

Jimenez-Jimenez, D., Cegarra-Navarro, J. G. (2007). The performance effect of organizational learning and market orientation. Industrial Marketing Management, 36, 694-708.

Karahanna, E., Straub, D.W., Chervany, N.L. (1999). Information technology adoption across time: A cross-sectional comparison of pre-adoption and post-adoption beliefs. MIS Quarterly, 23(2), 183-213. 
King, W. R. (2004). Outsourcing and the future of it. Information Systems Management, 21(4), 83-84.

Kirca, A. H., Jayachandran, S., Bearden, W. O. (2005). Market orientation: a meta-analytic review and assessment of its antecedents and impact on performance. Journal of Marketing, 69(2), 24-41.

Kohli, A. K., Jaworski, B. J. (1990). Market orientation: The construct, research propositions, and managerical implications. Journal of Marketing, 54(2), 1-18

Krohmer, H. (1999) Marktorientierte Unternehmenskultur als Erfolgsfaktor der Strategie-implementierung. Gabler: Wiesbaden.

Kumar, V., Reinartz, W. (2006). Customer Relationship Management: A Databased Approach. John Wiley \& Sons: New York.

Lee, T-S., Tsai, H-J. (2005). The effects of business operation mode on market orientation, learning orientation and innovativenesss. Industrial Management \& Data Systems, 105(3), 325-348.

Lumpkin, G. T., Dess, G. G. (1996). Clarifying the entrepreneurial orientation construct and linking it to performance. Journal of Academy of Management Review, 21(1), 135-172.

McGuinness, T., Morgan, R. E. (2005). The effect of market and learning orientation on strategy dynamics: The contributing effect of organisational change capability. European Journal of Marketing, 39(11), 1306-1326.

Mengüc, B. (1996). The influence of the market orientation of the firm. International Journal of Research in Marketing, 13(3), 277-291

Miller, D. (1983). The correlates of entrepreneurship in three types of firms. Management Science, 29(7), 770-791.

Miller, D., Friesen, P. H. (1978). Innovation in conservative and entrepreneurial firms: Two models of strategic management. Strategic Management Journal, 3, 1-25.

Narver, J. C., Slater, S. F. (1990). The Effect of a market orientation on business profitability. Journal of Marketing, 54(4), 20-35.

Neal, A., West, M. A., Patterson, M. G. (2004). Do Organizational Climate and Strategic Orientation Moderate the Relationship between Human Resource Management Practices and Productivity. Working Paper, London School of Economics and Politicial Science.

Newell, F. (2003). Why CRM Doesn't Work? Bloomberg Press, Princeton.

Nunnally, J. C., Bernstein, I. H. (1994). Psychometric Theory. McGraw-Hill: New York.

Pantaleo, G., Wicklund, R. A. (2000). Multiples perspectives: Social Performance beyond the single criterion. Zeitschrift für Sozialpsychologie, 31(4), 231-242.

Park, J-E., Holloway, B. B. (2003). Adaptive selling behavior revisited: An empirical examination of learning orientation, sales performance, and job satisfaction. Journal of Personal Selling and Sales Management, 23(3), 239-252. 
Peng, C.-H. (2008). The Relationships between the Antecedents of Innovativeness and Business Performance. ISECS '08 Proceedings of the 2008 International Symposium on Electronic Commerce and Security, 805-809.

Perez Lopez, S., Montes Peon, J. M., Vazquez Ordas, C. J. (2005). Human resource practises, organizational learning and business. Human Resource Development International, 8(2), 147-164.

Pirinen, R., Fränti, M. (2008). Framework and Culture of Proactive Competencies Learning Learning by Developing. WSEAS International Conference on Education and Educational Technology, 83-88.

Ramani, G., Kumar, V. (2008). Interaction orientation and firm performance. Journal of Marketing, 72(1), 27-45.

Rueckert, R. W., Walker, O. C.,Roering, K. J. (1985). The organization of marketing activities: A contingency theory of structure and performance. Journal of Marketing, 49(1), 13-25.

Saxe, R., Weitz, B. A. (1982). The SOCO scale: A Measure of the customer orientation of salespeople. Journal of Marketing Research, 19, 343-351.

Scholderer, J. (2000). Marktorientierung und Unternehmensperformance in der deutschen Biotechnologieindustrie. Working Paper: Potsdam.

Schwaab, C., Scholz, T. (2000). Was wird gelernt beim Organisationalen Lernen? Eine qualitative empirische Untersuchung. Zeitschrift Führung und Organisation, 6, 354-361.

Selnes, F., Jaworski, B. J., Kohli, A. K. (1996). Market orientation in United States and Scandinavian companies: A cross-cultural study. Scandinavian Journal of Management, 12(2), 139-157.

Severiens, S., ten Dam, G. (1998). A multilevel meta-analysis of gender differences in learning orientations. British Journal of Educational Psychology, 68, 595-608.

Siguaw, J. A., Brown, G., Widing, R. E. (1994). The Influence of the market orientation of the firm. Journal of Marketing Research, 31, 106-116.

Siguaw, J. A., Honeycut, E. D. (1995). An Examination of gender differences in selling behaviors and job attitudes. Industrial Marketing Management, 24(1), 45-52.

Sinkula, J. M., Baker, W. E., Noordewier, T. (1997). A Framework for marketbased organizational learning. Journal of the Academy of Marketing Science, 25(4), 305-318.

Slater, S. F., Narver, J. C. (1995). Market orientation and the learning organization. Journal of Marketing, 59(3), 63-74.

Spiro, R. L., Weitz, B. A. (1990). Adaptive selling: Conceptualization, measurement, and nomological validity. Journal of Marketing Research, 27(1), 61-69.

Steiners, D. (2005). Lernen mit Controllinginformationen. Gabler: Wiesbaden. 
Utzig, B. P. (1997). Kundenorientierung strategischer Geschäftseinheiten. Gabler: Wiesbaden.

Venkatraman, N. (1989). Strategic orientation of business enterprises: The construct, dimensionality, and measurement. Management Science, 35(8), 942-962.

Verhoef, P. C., Leeflang, P. S. H. (2009). Understanding the Marketing Department's Influence Within the Firm. Journal of Marketing, 73(1), 14-37.

Weitz, B., Sujan, H., Sujan, M. (1986). Knowledge, Motivation, and Adaptive Behavior: A Framework for Improving Selling Effectiveness. Journal of Marketing, 50(4), 174-191.

Wu, F., Mahajan, V., Balasubramanian, S. (2003). An Analysis of e-business adoption and its impact on business performance. Journal of the Academy of Marketing Science, 31(4), 425-447.

Zahra, S. A., George, G. (2002). Absorptive capacity. A Review, reconceptualization, and extension. Academy of Management Review, 27(2), 185-203.

Zheng, X., Cui, Y. (2007). Entrepreneurial Orientation, Market Orientation and Firm Performance: the mediator role of Organizational Learning. Proceedings of 2007 IEEE Xplore, 4391-4394.

\begin{abstract}
Abstrakt (in Polish)
Orientacja na interakcję odzwierciedla zdolność formy do interakcji z indywidualnymi klientami oraz do gromadzenia informacji uzyskanych $w$ tych interakcjach. Literatura przedmiotu podaje cztery wymiary orientacji na interakcję: koncepcja klienta, zdolność do reakcji, uprawomocnienie klienta oraz zarzq̨dzanie wartościq klienta (Ramani i Kumar, 2008). Niniejsza praca pokazuje piqty wymiar orientacji na interakcję oraz bada determinanty, moderatory i konsekwencje tej konstrukcji. Pierwszym odkryciem jest to, iż firmy działajqce w środowisku B2B wykazujq większy stopień interakcji niż firmy ze środowiska B2C. Ramani i Kumar przewidywali to w swojej pracy. Pokazujemy, że istniejq sektory B2C, jak na przykład usługi finansowe, w których firmy również wykazujq większy stopień orientacji na interakcję. Być może dlatego właśnie autorzy nie mogli udowodnić swojej hipotezy. Ponadto, badamy wpływ orientacji strategicznej na efektywność organizacji i porównujemy ze sobq różne orientacje.

Słowa kluczowe: adaptacyjna sprzedaż, dystans Cooka, sprzedaż nastawiona na klienta, orientacja przedsiębiorcza, środowisko, usługi finansowe, orientacja na interakcję, orientacja na uczenie się, orientacja rynkowa, kultura organizacyjna, strategia organizacyjna, struktury organizacyjne.
\end{abstract}

